\title{
Tüketim ve Tüketim Toplumu Kavramlarının Covid-19 Pandemi Süreci Çerçevesinde İncelenmesi
}

\section{Deniz YAMAN*}

**YÖK 100/2000 Doktora Bursiyeri, Süleyman Demirel Üniversitesi, Sosyal Bilimler Enstitüsü, İletişim Bilimleri dnizymn@gmail.com

Orcid ID: 0000-0002-3916-8244

Gönderilme/ Received 28.09.2021

Kabul Tarihi/ Accepted 15.10.2021

Yayın Tarihi/Published 17.11.2021
$\ddot{\mathrm{O} z}$

Derleme bir araştırma niteliği taşıyan bu çalışmanın amacı, postmodern toplumlarda gerçek bağlamından kopan tüketim ve tüketim toplumu kavramlarının Covid-19 pandemi süreci çerçevesinde incelenmesidir. Kapitalizm ile anılan tüketim toplumunda, tüketimin artık herhangi bir gereksinimden dolayı gerçekleşmediği, aksine bu yeni toplum yapısında tüketimin bizatihi bir ihtiyaç haline dönüştüğüne vurgu yapılmaktadır. Gerçek ile sahte ihtiyaçlar arasındaki ayrımın kaybolduğu tüketim toplumunda bir ürünü tüketmek, onun reklamlar aracılığıyla verilen anlamını da tüketmek demektir. Ancak, 2020 yılında meydana gelen Covid-19 küresel salgınının tüm dünyayı etkisi altına alması, bireylerin tüketim davranışlarında birtakım değişikliklere sebep olmuştur. Küresel salginın tetiklediği korku ve panik unsurları toplumları baskı altına almış; bunun yanı sıra pandemi sürecinde yeni tüketici profilleri ve ihtiyaç kaynaklı tüketim alışkanlıkları yaratmıştır. Araştırma kapsamında tüketim ve tüketim toplumu kavramlarına ek olarak, salgın döneminin bireylerin tüketim davranışlarına olan etkilerine de değinilmiştir. Bu sebeple, tüketici davranışlarının salgın sürecindeki değişimini odağa alan farklı araştırmalara ait bulgulara araştırma içerisinde yer verilmiştir.

Anahtar Kelimeler: Tüketim, Tüketim Toplumu, Tüketici Davranışları, Covid-19. 


\title{
Examination of Consumption and Consumer Society Concepts in The Framework of The Covid-19 Pandemic Process
}

\author{
Deniz YAMAN*
}

* Council of Higher Education 100/2000 PhD Scholar, Süleyman Demirel University, Graduate School of Social Sciences, Communication Sciences

dnizymn@gmail.com Orcid ID: 0000-0002-3916-8244

Gönderilme/ Received 28.09.2021

Kabul Tarihi/ Accepted 15.10.2021

Yayın Tarihi/Published 17.11.2021

\begin{abstract}
The aim of this study, which is a compilation research, is to examine the concepts of consumption and consumer society, which are detached from their real context in postmodern societies, within the framework of the Covid-19 pandemic process. In the consumer society associated with capitalism, it is emphasized that consumption is not realized due to any need anymore, on the contrary, consumption has turned into a need in this new society. Consuming a product in a consumer society, where the distinction between real and fake needs disappears, means consuming its meaning given through advertisements. However, the global epidemic of Covid-19, which occurred in 2020, affected the whole world and caused some changes in the consumption behaviors of individuals. The fear and panic elements triggered by the global epidemic have put societies under pressure; in addition, it has created new consumer profiles and need-based consumption habits during the pandemic process. In the scope of this research, besides the concepts of consumption and consumption society, the effects of the epidemic period on the consumption behaviors of individuals are also mentioned. Therefore, the findings of different studies that focus on the change in consumer behavior during the epidemic process are included in the research.

Keywords: Consumption, Consumer Society, Consumer Behavior, Covid-19.
\end{abstract}




\section{Giriş}

Tüketici, tüketim ve tüketim toplumu kavramları, postmodern kapitalist toplumları tanımlamak için kullanılan en temel kavramlardandır. Üretimin, kapitalist ve endüstriyel ilişkiler çerçevesinde biçim değiştirmesi, toplumsal anlamda önemli dönüşümlere neden olmuştur. Bu dönüşümlerin en başında, tüketim odaklı yeni toplum yapısında insani ilişkilerin değerini giderek yitirmesi gelmektedir. Özellikle, 1950'li yllardan itibaren internet ve iletişim teknolojilerindeki gelişmeler ile birlikte kapitalizmin altın çağını yaşamaya başlaması, hissedilen bu değer kaybının şiddetini giderek artırmıştır. Teknoloji ağları ile çevrelenmiş toplumlardaki bireylerin tüketim pratiklerinde radikal değişimler meydana gelmiş; nesneler artık sadece gereksinimleri karşılamak amacıyla değil, toplum içerisinde saygınlık kazanmak için de tüketilmeye başlanmıştır. Sonuç olarak yalnızca nesnelerin değil, anlamların da tüketildiği yeni bir dönem vuku bulmuştur.

Gelişen teknoloji ile birlikte çeşitlenen pazarlama stratejileri ve tüketim metalarının kişiselleştirilmesi sayesinde bireyler sürekli olarak tüketime güdülenmektedir. Bu durum, tüketim olgusunu manipüle etmekte ve tüketimin ihtiyaç bağlamının dışına çıkarak, toplumsal anlamda bir varoluş amacına dönüşmesine neden olmaktadır. Tüketim olgusunun "ihtiyaç" bağlamından koparıldığı tüketim toplumunda birey, göstergelerin hegemonyası altındadır. Öyle ki, birey satın aldığı tüketim metaları üzerinden kendi kişiliğini yansıttığına inanmakta; bu metalar aracılığıyla toplum içerisindeki statüsünü ve saygınlığını artırdığını düşünmektedir. Tüketim toplumunda birey, bir statüye sahip olmak ya da sahip olduğu statüyü sergileyerek toplumsal anlamda kabul görmek için daima daha çok tüketmek mecburiyetindedir. Bu mecburiyetten kaynaklanan tüketme arzusu, kitle iletişim araçları ve reklamlar aracılığıyla daha da artırılmakta, böylelikle tüketim olgusu bir yaşam felsefesi olarak benimsetilmektedir.

\section{Tüketim Toplumu: Tüketiyorum Öyleyse Varım!}

Jean Baudrillard (2021, s. 95) tüketim toplumunu, “... yeni üretim güçlerinin ortaya çıkmasıyla ve yüksek verimlilik taşıyan ekonomik bir sistemin tekelci yeniden yapılanmasıyla orantılı yeni ve özgül bir toplumsallaşma tarzı" olarak tanımlamaktadır. Çünkü tüketim olgusu artık göstergeler aracılığıyla kültürel bir sisteme entegre olmuştur. Kültürün yaygınlaşmasında büyük bir öneme sahip olan medya ve kitle iletişim araçları, metaları birer gösterge olarak bireylere sunmakta ve onları tüketime teşvik ederek bu yeni toplumsal yapının bileşenlerinden biri haline getirmektedir. Tüketim toplumunda tüketiciler, gereçler dünyasında yaşayan varlıklar olarak kabul edilmektedirler. Tüketime dayalı bilinç dünyayı istila etmekte ve artık, bu yeni düzende bireylerin karakterleri sahip oldukları aracılığıyla analiz edilebilmektedir (Joy ve Wallendorf, 1996, s. 107).

Zygmunt Bauman da, Baudrillard'ın düşüncesine benzer bir şekilde postmodern toplumun bir tüketim toplumu olduğuna vurgu yapmaktadır. Her toplumun farklı dönem ve toplumsal aşamalarında üretimin ve tüketimin mevcut olduğunu ifade eden Bauman (2016, s. 92), tüketim toplumlarının geçmişte 
"üretim" ile öncelenirken, günümüzde "tüketim" olgusu ile gündeme geldiğini belirtmekle birlikte tüketim toplumunun tüketicisini, bu zamana kadar herhangi bir toplumda eşi benzeri görülmemiş bir yaratık olarak tanımlamaktır. Bauman'a (1999, s. 99) göre, tüketim toplumunda yaratılan kültürün temel dinamiği öğrenme değil, unutmadır. Tüketim arzusu, tüketicilerin ihtiyaçlarının veya edinilmiş gereksinimlerinin çizmiş olduğu sınırların çok ötesine geçmiştir. Tüketim toplumunda ihtiyaçlar ve tatmin arasındaki geleneksel ilişki tersine dönmüş ve tatmin vaadi, mevcut ihtiyaçtan daha önce gelmeye başlamıştır.

Tüketim toplumundaki bireyin en temel vazifesi, önceden düzenlenmiş, çeşitlendirilmiş mal ve hizmetleri arzulamak, onlara sahip olmak için çalışmak ve en sonunda onları satın alarak kapitalist sistemin sürdürebilirliğini sağlamaktır (Ince, 2014, s. 28). Tüketim toplumunun başat parolası, mutluluk kavramıdır. Mutluluk, kapitalist çağda her şeyin ve herkesin sığınağı olagelmiştir. Bu mutluluğun temel ölçütlerini nesneler, semboller ve göstergelerin tüketimi oluşturmaktadır (Zorlu, 2016, s. 221). Tüketim toplumu, satın almış olduğu ürün veya hizmetin hazzını henüz tüketmeden, yeni ve farklı ihtiyaçların memnuniyetsizliğini yaşayan bireylerden oluşmaktadır (Kaban Kadıoğlu, 2014, s. 47). Bu yeni dönemde bireyler, tatmin duygusunun kışkırtması ile tüketim nesnelerine sürekli ve yeniden arzu duymakta, süreğen bir hoşnutsuzluk ve yoksunluk hissi duyumsamaktadırlar (Köse, 2008, s. 1).

Baudrillard (2011, s. 236), tüketim toplumundaki statü kavramının giderek basitleştiğini ve bu kavram ile yaşam düzeyi kavramının çakışma eğiliminde olduğunu ifade etmektedir. Sorumluluk, otorite veya iktidar kavramlarıyla ilişkilendirilen "yaşam düzeyi" nosyonuna karşılık olarak reklamlarda nesneler ile kişilik özellikleri arasında anlamsal bir bağ yaratılmaktadır. Yani tüketim toplumunda bireyi tanımlama girişimi, sahip olduğu nesneler üzerinden gerçekleşmektedir. Nesnenin kendisinde olmayan anlam, ona başkaları tarafından yüklenmiştir. Öyle ki, bu durum insanlardaki "benlik" duygularının gelişmesini kapsayan olgularla iç içe geçmiş bulunmaktadır (Bocock, 2005, s. 10).

Adorno (2004, s. 92-94), tüketim metalarındaki üretim fazlası ve çeşitliliğin bireyleri tüketime bağımlı kıldığını ifade etmekte; sahte ihtiyaçları ise, endüstriyel kültürün bireylere ihtiyaçmış gibi dayatarak yaşamlarına soktuğu şeyler olarak nitelemektedir. Adorno'ya (2007, s. 124) göre, ihtiyaçlar üretim metalarına uyarlanırlar ve araçlar neleri nasıl üretiyorlarsa, kişilerin ihtiyaçları da o araçlara göre tekrar düzenlenirler. Bu noktadan sonra nelerin, bireylerin ne kadar ihtiyacını karşıladıkları belirsizleşir, dahası sahte ihtiyaçlar ortaya çıkmaya başlar. Bireylere tüketim metaları bakımından neredeyse sınırsız bir çeşitlilik sunulur. Ancak tüm bu çeşitlilik ortamında bireyin kendi yolunu bulması imkânsızlaşmaktadır. Tüketimin başlı başına bir ihtiyaç ve amaç haline geldiği tüketim toplumunda bireyler, boş zamanlarını açık alanlarda veya parklarda geçirmek yerine hipermarketlerde geçirmektedirler. Binlerce ürün gamına sahip olan hipermarketlerde bireylere sınırsız bir çeşitlilik sunulmaktadır. İçerisinde çocuk parkından kafeteryaya kadar bilumum eğlence noktalarının mevcut olması, hipermarketleri birer çekim merkezi haline getirmektedir. Bu çekim merkezlerinin girdabına kapılan birey, hiç ihtiyacı olmayan ve hesapta bulunmayan alışverişler gerçekleştirmektedir. Dolayısıyla 
satın alma eyleminin altında yatan temel sebep, ihtiyaçları karşılamak değil, tüketim yoluyla stres atma ve rahatlama arzusudur (Aslan, 1996, s. 14).

Featherstone'a (2013, s. 155), tüketim kültürünün benimsendiği postmodern tüketim toplumunun yeni bir tüketici profili meydana getirdiğini öne sürmektedir. Söz konusu tüketici, geleneksel bağlarından ve mevcut alışkanlıklarından koparak, yaşam tarzlarını bir proje olarak ele almaktadır. Diğer bir deyişle birey, sahip olduğu nesneleri sergileyerek kendini toplum içerisinde görünür kılma çabası içerisine girmiş bulunmaktadır. Ayrıca bu yaşam biçimi yalnızca varlıklı insanlar ya da gençler arasında değil, tüketim kültürünün egemen olduğu toplumun büyük çoğunluğu tarafindan da benimsenmektedir.

Jean Baudrillard, günün kitle kültürünü, insanlığın ulaştığı bir distopya olarak nitelemektedir. Bu distopya, tüketimin başat hale geldiği bir toplumun ürünüdür. Baudrillard tüketim toplumundan, "özgürlük" parolasıyla herkesin herkesle rekabet halinde olduğu bir ortam olarak bahsetmektedir. Öyle ki, tüketim metalarına ulaşmak toplumsal açıdan var olmanın başlıca gerekliliği haline gelmiştir. Metalar tarafından kuşatılmış birey, değişim değeri prangasına bağlı bir şekilde tüketmek, daima daha çok tüketmek zorundadır (Kulak, 2017, s. 56). Veblen (2015), "Aylak Sinıfin Teorisi" adlı eserinde tüketim toplumuna yönelik çarpıcı eleştirilerde bulunmaktadır. Tüketim toplumunun bir parçası haline gelen birey için biyolojik ihtiyaçların tatmin edilmesi ve tüketim arasında hiçbir bağ yoktur. Tüketim olgusunun biyolojik olarak var olma boyutunun önüne geçtiğine dikkat çeken Veblen, bireysel tatmin elde etmenin yalnızca toplumsal çerçevede bir statü arayışından ibaret olduğunu ifade etmektedir. Zenginlik, toplumun yararı için kullanılmak yerine israfa yönlendirilmekte ve bu tutum bütün kesimler tarafından da taklit edilmektedir.

Baudrillard'a (2021, s. 47), tüketim toplumunun var olabilmesinin altında yatan temel dinamiği şu cümlelerle ifade etmektedir:

"Tüketim toplumu var olmak için nesnelere ihtiyaç duyar, daha doğrusu onları yok etmeye ihtiyaç duyar. Nesnelerin "kullanım"ı sadece nesnelerin yavaş yavaş kaybolmasına götürür. Nesnelerin şiddetle yitirilmesinde yaratılan değer çok daha yoğundur. Bu yüzden yok etme, üretime temel alternatif olarak kalır: Tüketim sadece üretimle yok etme arasındaki aracı bir terimdir. Tüketimde, kendisini yok etmede aşmaya, dönüştürmeye yönelik derin bir eğilim vardır. İşte burası tüketimin anlam kazandığı yerdir.”

Baudrillard (2021, s. 110-111), sanayi sonrası toplumda tüketilen nesnelerin, işlevsel pratiği, mülkiyeti ya da basit saygınlık sağlama fonksiyonunun ötesinde, "iletişim ve değiş tokuş sistemi olarak durmadan verilip alınan ve yeniden yaratılan göstergeler kodu olarak" ön plana çıktığı bir süreci işaret etmektedir. Örneğin, soy veya doğuma dayalı farklılıklar eski dönemlerde takas edilememekteydi. Çünkü bunlar yalnızca öze aittiler ve dolayısıyla tüketilemiyorlardı. Buna karşın, tüketim toplumundaki farklılıklar (giysi, anlam vb.) geniş bir tüketim müştereği içerisinde değiş̧ tokuş edilmektedir.

Insanların gösteri arzusu ile biçimlenen tüketim toplumunda medya, teknoloji ve kitle iletişim araçları kitleleri göstergelere yönelttiğinden dolayı büyük önem arz etmektedir. Bu göstergeler anlamdan yoksun olmakla birlikte, 
tüketimde esas rol oynamaktadırlar. Çünkü göstergelerde kitleleri çeken marka ve prestij unsurlarıdır (Toffoletti, 2014, s. 31-32). Bu nedenle tüketim toplumunda reklam ve moda, kitle kültürünün yaşam iksirleridir. Çünkü marka, toplum içerisinde belli bir statü veya ilişkiyi temsil eder. Dolayısıyla, bireyler üründen ziyade markanın logosunu tüketirler. İçinde yaşanılan toplumun, tüketim toplumu olarak atfedilmesinin nedenlerinden biri de de budur (Baudrillard, 2021, s. 254). Tüketim toplumunda, kodun hegemonyası belirleyicidir. Herhangi bir model kodlar vasıtasıyla nesneler düzleminde belirlenir ve belirlenen modeller de çoğu zaman bir logo ile tescillenir. Modelin ve logonun kitleler tarafindan benimsenmesi, toplum içerisinde onu bir arzu nesnesi haline getirir. Böylece kitleler ilgili modelin ya orijinalini ya da taklidini almak için kıyasıya bir mücadeleye girişir. Çünkü model, kitleler tarafından kabul gördüğü andan itibaren artık bir göstergeye dönüşür (Baudrillard, 2009, s. 59).

Gösterge kavramının tüketim olgusunu tanımlamada kullanılmasının nedeni, tüketimde gösterge lojiğinin egemen olmasından kaynaklanmaktadır. Baudrillard'a (2009, s. 60) göre bu düşünce sistematiğinde dört temel mantık biçimi bulunmaktadır: Kullanım değerinin işlevsel mantığı, değişim değerinin ekonomi mantığı, gösterge/değerin ayrımlayıcı mantığı ve son olarak simgesel değiş̧ tokuş mantığı. Bu mantık biçimlerinden ilki somut işlevlerle, ikincisi eşdeğerlikle, üçüncüsü karşıt anlamlılıkla ve son olarak dördüncü mantık biçimi ise farklılıkla ilişkilendirilmektedir. Bu dörtlü, eş deyişle yararlılık, piyasa, armağan ve statü mantığı olarak da isimlendirilebilmektedir. Değerlendirildiği ve tabi tutulduğu mantık biçimine göre nesne, bir araç, meta, simge ya da gösterge statüsü kazanabilmektedir. Kısaca, nesnenin erişebileceği en son nokta göstergedir. Gösterge halini alan nesne artık kültürün bir parçası olmaktadır (Okullu, 2019, s. 57-58).

Jean Baudrillard'a (1988, s. 21) göre, tüketim tüm hayatı kuşatmıştır. İnsanların bütün faaliyetlerinin tüketime göre biçimlendiği bir toplumda, tüketmek medeni olmanın ölçütü durumuna gelmiştir. Bireyin ihtiyaçlarını doyuma ulaştırmak için tüketmesi beklenirken, tüketmek zamanla ihtiyaç ve karşlama ilişkisinin çok ötesine geçmiştir. Tüketim toplumunda, bireylerin yapmış olduğu her tüketim tercihi kişiye ilişkin nitelikleri sembolize eder. Bir diğer deyişle, her tüketim metası insana dair bir imdir. Bir nesnenin, tüketim nesnesi olabilmesi için artık öncelikle bir im olması gerekmektedir. Çünkü tüketim, artık yalnızca nesnelerin tüketimi değildir; anlamların da tüketildiği moral bir alan, bir toplumsallaşma ve iletişim alanıdır (Kulak, 2017, s. 61). Tüketim toplumunda nesne, ihtiyaçları tatmin etme özelliğini kaybederek göstergeye; bu nesnelere sahip olanlar da göstergeyi tüketene dönüşmüştür. Her ne kadar bu nesneler postmodern tüketimde son derece kısa ömürlü olsalar da, tüketicilerin anlam ve arzu ihtiyaçlarını karşılamaya ilişkin çabaları sonucunda hızla tüketilmektedirler (Baudrillard, 2021, s. 27).

\section{Tüketim Türleri}

\subsection{Zaruri Tüketim}

Zorunlu tüketim, insanların yaşamlarını sürdürebilmeleri için gerekli olan beslenme, barınma, giyinme gibi ihtiyaçların karşılandığı tüketim biçimidir (Odabaşı, 2006, s. 18). Modern öncesi dönemde, üretmenin sonucu olarak 
değerlendirilen ve çoğunlukla temel gereksinimlerle sınırlı olan tüketim olgusu, bireyin yalnızca hayatta kalabilmek için tükettiği bir anlama karşılık gelmektedir (Şüküroğlu, 2017, s. 27).

\subsection{Gösterişçi Tüketim}

İlk etapta birey, ürün ve hizmetleri temel gereksinimlerini karşllamak, can ve mal güvenliğini sağlamak maksadıyla tüketmektedir. Ancak, her toplumda temel ihtiyaçların dışına çıkan, toplum içerisinde saygınlık ve statü kazanmak amacıyla tüketen, gösteriş meraklısı insanlar bulunmaktadır. Söz konusu tüketiciler için gösteriş metalarına erişmek, temel gereksinimlerinden daha fazla önem arz etmektedir (Hiz, 2011, s. 116).

Odabaşı'ya (2006, s. 18) göre, bireyin kendisini sürekli olarak başkalarıyla kıyaslamasına dayanan gösterişçi tüketimin temelinde farklı olma arzusu yatmaktadır. Birey, ayrıcalıklı olarak kabul ettiği topluluk tarafindan kabul görmek, fark edilmek veya ondan kopmamak adına sürekli olarak tüketmek mecburiyetindedir.

\subsection{Sembolik Tüketim}

Fikir ya da nesne farklı şeylerin yerine geçerek onları niteleyen işaretler olarak tanımlanan sembol kavramı, logo, jest, sözcük, resim veya ürünlerden oluşmaktadır. Semboller, herhangi bir şeyi saptamaya yarayan göstergelerdir. Sembolik tüketim ise nesnelerin, taşıdıkları sembolik özellikler bağlamında değerlendirilip bu doğrultuda satın alınıp tüketilmesi durumudur (Azizoğlu ve Altunışık, 2012, s. 35).

Bocock’a (2005, s. 57-58) göre, tüketim metaları önceden hazırlanmış, düzenlenmiş, yaratılmış ve böylece tüketicinin onu arzulayacağı şekilde kodlanmiştır. Tüketiciler fiziksel olarak son derece edilgen fakat zihinsel olarak ise oldukça meşguldürler. Ayrıca, sembolik tüketimin ve satın alma eyleminin artık bir güdü haline geldiği tüketim toplumunda bireyler, temel ihtiyaçlarını karşılayarak hayatlarını idame ettirebilmek için değil, tüketim metalarını satın alabilmek için çalışmaktadırlar. Tüketim toplumunda ürünler, sembolik metalar haline gelmiştir. Odabaşı'na (2006, s. 83) göre, sembolik tüketim kapsamında birey içinde yaşadığı topluma, tükettiği ürünler aracılığıyla nasıl bir insan olmayı arzuladığına veya olduğuna ilişkin mesajlar vermektedir. Sembolik ürün tüketimi, kendini tanımlamak, toplumsal anlamda kabul görmek, statü belirtmek veya sınıf atlamak gibi amaçlar dâhilinde yapılmaktadır.

Çelik'e (2009, s. 77) göre, sembolik tüketimin temel nedenleri şunlardır:

$>$ Statü ve saygınlık göstergesi

> Metalar üzerinden kendi kimliğini tanımlamak ve arzuladığı role bürünmek

> Sosyal benliğini yaratmak ve korumak

$>$ Kendini ifade etmek

$>$ Kimliğini aktarmak 


\subsection{Postmodern Tüketim}

Baudrillard, yeni üretim şekillerinin modern endüstri toplumunun sınırlarının çok ötesinde bir tüketim toplumu olan postmodern toplumda taklitler yoluyla yayıldığını ifade etmektedir. Bu yeni toplum düzeni, önceden belirlenmiş tüketim biçimlerinden ve sahte bir gerçeklikten oluşmaktadır (Aktulay Çakır, 2014, s. 55). Bir diğer deyişle postmodern kültür, göz alıcı bir biçimde gerçeküstü yeni bir toplum düzeni yaratmıştır. Sanayi sonrası toplum, yalnızca tüketime programlanmış ve kodlanmış, kendini sibernetik şekilde murakabe eden bir toplumdur. Insanlar, kodlar vasitasıyla medya ve kitle iletişim araçlarından mesajlara maruz kalarak yeni tüketim şekillerini taklit etmeye başlarlar (Kellner, 1994, s. 231-232).

\subsection{Hedonik (Hazcı) Tüketim}

Hedonik (hazcı) tüketim kavramının daha iyi anlaşılabilmesi için ilk olarak hedonizm kavramını tanımlamak yararlı olacaktır. Hedonizm, hazzın en mutlak iyilik olarak kabul edildiği, haz arayışına adanan bir hayat öğretisine ilişkin felsefi görüştür. Hazcı tecrübeler, eğlence, fantezi, kışkırtma ve özellikle de zevk kavramları ile bağlantılıdır (Hopkinson ve Pujari, 1999, s. 274).

Hedonik tüketim kavramını ilk kez kullanan Hirschman ve Holbrook (1982, s. 92) bu tüketim biçimini, birden fazla duyuya aynı anda hitap ettiği, satın alma tutumlarının fantezi dünyasını beslediği, ürün ve hizmete yönelik deneyimlerin heyecan verici durumlar yarattığı, tüketici davranışlarına ilişkin farklı boyutlarla ilişkilendirmektedir. Arnold ve Reynolds (2003, s. 80) ise hedonik tüketimi, birden çok duyuya seslenen, duygu veya fantazya ile ilişkili davranış boyutları olarak ifade etmektedirler. Bu tanımlar çerçevesinde değerlendirildiğinde özellikle vurgulanan nokta, hazcı tüketim sürecinin birden fazla duyuyu eşzamanlı olarak devreye sokması durumudur. Özellikle ürün veya hizmetlerin pazarlanması için hayati öneme sahip olan reklamlarda ve alışveriş ortamlarında ses (müzik), koku ve tasarım gibi duyulara hitap eden unsurlar büyük bir özveri ile planlanmak ve uygulanmaktadır (Kükrer, 2011, s. 80).

Pazarlama stratejilerinin geleneksel bağlamından koparak modernleşmesi, tüketim olgusunda radikal değişikliklerin yaşanmasına neden olmuş, bunun sonucunda marka ve kuruluşlar da pazarlama faaliyetlerinde ürünlerin kullanım değerlerinden ziyade tüketiciye sunduğu hazzı ya da duygusal deneyimleri ön plana çıkarmayı amaçlamışlardır (Özgül, 2011, s. 26). Khan ve çalışma arkadaşları (2005, s. 146), alışveriş tutumlarını yönlendiren ürünleri, ihtiyaç duyulan veya lüks ürünler, pragmatik veya hedonik ürünler, fakirlik veya zenginlik göstergesi ürünler olarak sınıflandırmaktadırlar. Örneğin, gıda ve giyim gibi yaşamın temel gereksinimlerini gideren ürünler zaruri ürünler kategorisinde yer alırken; konfor sunan ya da keyif veren fantezi ürünler lüks ürünler olarak kategorize edilmektedir. Arnold ve Reynolds (2003, s. 81-82), bireyleri hedonik tüketime teşvik eden 6 temel etken olduğunu vurgulamaktadırlar. Bu etkenler şunlardır: maceracı alışveriş, sosyal amaçlı alışveriş, rahatlatıcı alışveriş, fikir edinme amaçlı alışveriş, başkalarını mutlu etme amaçlı alışveriş ve değer amaçlı alışveriş. 


\section{Tüketim Toplumunun Temel Unsurları}

\subsection{Nesneler Sistemi}

Jean Baudrillard'ın tüketim olgusuna ilişkin düşüncelerinde nesneler maddi şeyler olarak değil, göstergeler olarak tanımlanmaktadır. Nesnenin, tüketim nesnesi olarak atfedilebilmesi için öncelikle bir gösterge olmasının gerekliliğini ifade eden Baudrillard'ın vurgulamak istediği asıl nokta, insanların nesneler üzerinden göstergeleri tükettiğidir (Toffoletti, 2014, s. 76). Bu ifadeden hareketle Jean Baudrillard'ın nesneyi geleneksel bağlamından farklı bir şekilde ele alarak yorumladiğı söylenebilmektedir.

Baudrillard'a (2012, s. 28) göre, tüketim toplumunda özne ile nesnenin konumu tersine dönmüş, bu yeni düzende nesne öznenin yerini almıştır. Dolayısıyla, nesne artık özenin teveccüh ettiği bir şey olmaktan çıkmıştır. Nesnenin özne tarafından keşfedilmesi, öznenin de nesne tarafindan keşfedildiği bir süreci başlatmıştır. Tüketim sürecinde nesne, özneyi belirleyen ya da yönlendiren bir konuma geçmiştir. Nesne tarafından kuşatılan özne artık sadece seçme hakkına nail olmakla birlikte, seçmeme hakkından mahrum bırakılmıştır (Baudrillard, 2013, s. 146).

Jean Baudrillard'ın (2013, s. 107) düşüncesinde nesnelerin iki farklı işlevi bulunmaktadır. Bunlardan ilki "işe yaramak"; diğeri ise "birinin malı olmak"tır. Nesneleri göstergeler üzerinden tanımladığından dolayı Baudrillard için nesnenin öncelikli işlevi, birinin malı olması durumudur. Çünkü bir nesneye sahip olan tüketici, kültürel sistemin bir parçası olmakta ve böylelikle simülasyon düzleminde karşllaştığı göstergeyi tüketmektedir. Ancak Baudrillard'a (2021, s. 163) göre tüketilen şeyler içerisinde diğer nesnelere nazaran daha özel, daha güzel ve daha kıymetli bir nesne vardır; bu nesne bedendir. Kitle kültüründe beden, reklam ve moda aracılığıyla nesne pozisyonuna indirgenmiştir. Bedenin kilo unsuru ile biçimlendirilerek sunulması, cinsellik ve cinsiyet göstergelerini, beden bakımı ve sağlığı ile alakalı göstergeler ise bedenin fonksiyonunu bertaraf etmiş; bu durum bedenin ilgili göstergeler çerçevesinde değerlendirilmesine sebep olmuştur. En nihayetinde beden, tüketim toplumunda artık bir göstergeden ibaret olmuş ve tüketim nesnesi haline gelmiştir. Nesne haline gelen beden, maddi boyutunu ve özneye ilişkin olma özelliğini kaybetmiştir.

\subsection{Yaşam İksiri: Reklam}

Reklam, tüketim toplumunun temel yapı taşlarından biridir. Baudrillard düşünselinde reklam, nesnelerin sisteminin tamamlayıcı bir parçasıdır (Toffoletti, 2014, s. 83). Çünkü reklam aracılığıyla tüketici toplumsal nizama dâhil edilmektedir. Ayrıca reklamlar, modanın belirlendiği ve kültürel göstergelerin teşhir edildiği gösterim alanlarıdır. $\mathrm{Bu}$ sebeple reklam, kitle kültürünün yaratılması ve yayılması hususunda büyük önem arz etmektedir (Baudrillard, 2021, s. 156).

Jean Baudrillard (2011, s. 215-216), reklam göstergelerinin tüketicilere nesnelerden söz ettiğini, fakat onları hangi misyon doğrultusunda kullanmaları gerektiğinden söz etmediğini ifade etmektedir. O’nun düşüncesine göre bu göstergeler her ne kadar gerçek referanslara sahip olsalar da, aslında var olmayan bir dünyayı sergilemektedirler. Baudrillard, bu noktada reklamın bir 
aldatmacadan ibaret olduğunu vurgulamaktadır. Gerçekte var olmayan bir şeyin reklam vasıtasıyla sunulması, düşsel bir tatmin duygusu sağlamamasının yanı sıra gerçek dünya ile ilişki kurulması noktasında da uyumsuzluklara yol açar. Dolayısıyla hayal kırıklığı ile sonuçlanan arzular, asla doyuma ulaşmayacak tüketim ihtiyaçlarını meydana getirirler.

Reklam, tüketim toplumunda ikircikli bir rol üstlenmektedir. Diğer bir deyişle reklam, içerisinde bir tür helezoni barındırmaktadır. Öyle ki, reklam tüketiciyi hem bunaltma hem de rahatlatma amacı taşır. Bir taraftan bireyin bütün hayallerini gerçekleştirmekte, diğer taraftan ise onu düş kırıklığına uğratmaktadır. Bunun sonucunda birey, reklam aracılığıyla her şeyi arzulayan bir hale gelmekte ve yaratılan düzenin bir parçası olmaktadır (Baudrillard, 2011, s. 217).

\subsection{Sanal Olanın Yaratıcısı: Teknoloji}

Teknoloji ve medya, simülasyon düzeninin oluşturulmasındaki en büyük etkenlerdendir. Gelişen teknoloji sonucunda medyada sanal bir dünya yaratılmış ve nihayetinde gerçek dünya ortadan kaldırılmıştır. Jean Baudrillard (2012, s. 12-13), "bu durumda insanın ortadan kaybolup gittiği bir dünyadan" söz edilebileceğini ifade etmekte ve "iletişim araçlarıyla sanal teknolojinin ortaya çıktığı ve her yerin değişik tipte ağlarla kaplandığı bir çağda gerçekliğin katledildiğini" vurgulamaktadır. Baudrillard'a (2012, s. 56) göre, "teknolojik gelişme, insanoğlunun kendi varoluşuna inanmaktan artık vazgeçtiği, kendini sanal bir varlık, vekâleten bir yazgı olarak belirlediği anlamına gelebilir.” Çünkü gerçekliğin ortadan kalkması durumu insanları amaçtan yoksun bırakarak, onların sükûta ve tepkisizliğe sürüklemektedir.

Bireyler, teknoloji ve internet aracılığıyla sanal kimlikler yaratabilme imkânına sahip olmuşlardır. Bu durum, tüketim toplumunda bireylerin sanal varlıklarının, maddi ve canlı var oluşlarının önüne geçmesine neden olmuştur. Özellikle sosyal medya uygulamalarının geliştirilmesi ve kullanımının yaygınlaşması sonucunda bireyler, sanal uzamda sahip oldukları nesneleri ve yaşadıkları hayatı sergileyerek sanal bir statü üretmeyi veya toplum içindeki statüsünü sergilemeyi arzulamaktadırlar. Sanal uzamda fenomen olarak nitelendirilen model profiller, kullanıcılar tarafindan arzu nesneleri haline gelmişlerdir. Bu modeller, lüks yaşama vurgu yapan nesneleri sosyal ağlarda sergileyerek, insanları tüketime teşvik etmektedirler. Tüketimin sanal bir gösteriye dönüştügü sosyal ağlarda bireyler kişiliklerini nesnelerin temsil ettiği gösterge ve imajlar üzerinden tanımlayarak bu gösterinin bir parçası haline gelmektedirler.

\section{Covid-19 Pandemi Döneminde Değişen Tüketici Davranışları}

Tüketim olgusu ekseriyetle bir gereksinim veya istek sonucunda ortaya çıkmaktadır. Örneğin, beslenme ihtiyacı evrensel bir gerekliliği ifade ederken, istek ise bireye özgü kişisel tercihleri nitelemektedir (Bakırtaş ve Demirhan, 2015, s. 77). Baudrillard (2021, s. 46) ise, kültür endüstrisinin kıskacında kalan tüketim olgusunun artık yalnızca faydacı bir amacı olmadığını, göstergelerin ve anlamların da tüketildiği bir süreci kapsadığını belirtmektedir. Ayrıca, Baudrillard (2021, s. 28) tüketim olgusunun yerinin saptanabileceğini şu ifadelerle açıklamaktadır: 
"Tüketimin yeri günlük yaşamdır. Günlük yaşam yalnızca günlük olayların ve hareketlerin toplamı, sıradanlığın ve yinelemenin boyutu değil, bir yorumlama sistemidir. Gündelik bütünsel bir praksisin (siyasalın, toplumsalın ve kültürelin) aşkın, özerk ve soyut bir alanıyla "özel”in içkin, kapalı ve soyut alanı olarak bölünmesidir."

İnsan, varoluşundan itibaren farklı tarihsel dönemlerde zuhur eden savaşlar, ekonomik krizler, doğal afetler ya da salgın hastalıklar gibi bireysel ve toplumsal yaşamı tehdit eden, sinırlayan veya yıpratan birçok zorlukla mücadele etmiştir. 21. yüzyıl bağlamında değerlendirildiğinde, insanlık en büyük savaşını tüm dünyayı etkisi altına alan, büyük kayıplara yol açan ve toplumsal yaşamı durma noktasına getiren Covid-19 küresel salgınına karşı vermektedir. Virüsün yüksek bulaşıcılığa sahip olmasından dolayı sosyal faaliyetler sınırlandırılmakta; insanların yoğun kitleler halinde bir arada bulunduğu alışveriş merkezleri, yemek ve eğlence mekânları da bazı kısıtlamalara tabi tutulmaktadır. Bu kısıtlamalar, ontolojik olarak kendi benliğini tüketim olgusu ekseninde kurgulayan bireylerin tüketim davranışlarında korku kaynaklı birtakım değişikliklerin meydana gelmesine sebep olmaktadır.

Türkiye'nin en büyük izinli veri tabanına sahip çevrim içi pazar araştırma şirketi olan DORinsight, "salgından sonra değişen tüketici davranışları" konulu araştırması kapsamında Türk halkının satın alma önceliklerinin nasıl değiştiğini incelemiştir. 5007 kişinin katılımıyla gerçekleştirilen araştırmanın bulgularına göre, erkek katılımcıların \%84'ü, kadın katılımcıların ise \%92'si Covid-19 döneminde satın alma davranışlarının değiştiğini ifade etmiştir. Katılımciların \%60'ı, salgın döneminde gıda harcamalarının arttı̆̆ını vurgulamış; \%63’ü tatil planlarını ertelediğini, \%72'si araba veya gayrimenkul gibi yatırımlar yapmayı düşünmediklerini, \%86'sı da tedbire dayalı zorunlu sosyal izolasyon sürecinde sosyal medya kullanımlarının arttığını belirtmiştir (https://mediatrend.mediamarkt.com.tr/). Soylu (2020), Covid-19 küresel salgınının tüketici davranışlarına olan etkisini saptamak amacıyla Türkiye'nin farklı bölgelerinde yaşan 3391 kişiye anket ölçeği uygulamıştır. Araştırmanın bulgularına göre, tüketicilerin temizlik ürünlerine yönelik taleplerinin arttığı, banka kartlarındaki temassız ödeme limitinin yükseltildiği ve elektronik bankacılık uygulamalarının kullanımının yaygınlaştığı gibi bilgilere ulaşılmıştır.

Uluslararası yönetim danışmanlık firması McKinsey \& Company (2021) tarafindan yayınlanan, Covid-19'un tüketiciler üzerindeki kalıcı etkilerine yönelik değerlendirmelerin yer aldığı raporda, tüketicilerin pandemi döneminde dijitali daha fazla benimsemelerinin yanı sıra ev dişında harcanan para ve zamanda kesintilerin meydana geldiğine dair ifadelere yer verilmiştir. Ayrıca raporda, sanal sağlık hizmetleri ve çevrim içi market alışverişi gibi tüketici tutumlarının salgın dönemi sonrasında da kalıcı olacağının altı çizilmiştir.

Scott Baker ve çalışma arkadaşlarının (2020), hane halkı tüketimi ve küresel salgın arasındaki ilişkinin ABD'deki yansımalarını incelediği araştırmada, tüketim davranışlarının mevcut vaka sayılarının artmasıyla yapısal olarak değişiklik geçirdiğini gözlemlemişlerdir. Araştırmada salgının erken dönemlerinde, özellikle de gıda ürünlerinin satın alımlarında muazzam harcamaların yapıldığı; lakin, sosyal izolasyon prosesinin başlamasıyla birlikte 
tüketicilerin genel ve hizmet sektörüne ilişkin harcamalarında düşüş yaşandığı tespit edilmiştir. Eichenbaum ve arkadaşları (2020) tarafından yapılan, salgının arz ve talep dengesi üzerindeki etkilerini odağa alan bir başka araştırmaya göre ise, bireylerin sosyal izolasyon tedbirlerine tabi tutulmaları ve toplumsal hareketliliğin sınırlandırılması gibi uygulamaların salgının şiddetini düşürdüğü sonucuna ulaşılmıştır.

Rogers ve Cosgrove (2020, s. 1-4), Covid-19 sürecinin tüketici davranışlarını nasıl değiştirdiğini araştırmak amacıyla ABD, Ingiltere, Fransa, Kanada ve Almanya olmak üzere beş farklı ülkede yaşayan 4859 tüketiciden (katılımcıdan) veri toplamışlardır. Araştırma sonucunda, pandemi döneminin dört farklı tüketici profili yarattığı belirlenmiştir. Bunlar; stokçu tüketiciler, tedbirli tüketiciler, sabit tüketiciler ve sağlamcı tüketicilerdir. Stokçu tüketiciler, en çok market gereksinimlerine harcama yaparken, tedbirli tüketiciler ise yalnızca zorunlu ihtiyaçlara harcama yapmaktadırlar. Sabit tüketiciler bu süreçte tüketim alışkanlıklarında belirgin farklılıklar oluşmadığını belirtirken, sağlamcı tüketiciler ise pandemi sonrasında satın aldıkları ürünlerin büyük oranda değiştiğini ifade etmişlerdir.

Yapılan araştırmalardan elde edilen bulgular bağlamında değerlendirildiğinde, Covid-19 salgın döneminin toplumlar nezdinde yaratmış olduğu korku ve temel gereksinimlere ulaşamama olasılığının beraberinde getirdiği psikolojik unsurlar, bireylerin tüketim pratiklerinde "ihtiyaç" unsurunu esas aldıkları yeni bir dönemi işaret etmektedir.

\section{Sonuç}

Yirmi birinci yüzyıl teknoloji çağında toplumsal yaşam, nesneler çevresinde yeniden düzenlenmekte; inşa edilen bu yeni düzende ihtiyaçları karşllamak için yapılan tüketim ortadan kalkarak, yerini tüketim ihtiyacına birakmaktadır. Tüketim nesneleri, bireylere sunulurken ihtiyacı tatmin etme özelliğinden ziyade taşıdığı anlamla ilişkilendirilmekte, böylelikle bireyler ilgili ürünleri ihtiyaçları olmasa dahi satın alma tutumu gösterebilmektedirler. Çünkü tüketim toplumunda nesne, kullanım değerinin dışında taşıdığı anlamın ve imajın yanı sıra nitelediği statü ve saygınlık unsurları ile bireye bir kimlik kazandırmaktadır. Lakin, 2020 yılında tüm dünya toplumlarını derinden etkileyen Covid-19 salgınının başladığı, özellikle de zorunlu izolasyonların gerçekleştiği salgınla mücadele döneminde, bireylerin tüketim davranışlarında zaruri değişimler meydana gelmiştir. Kaygı, korku ve panik halinin egemen olduğu bu dönemde tüketim olgusu, sanal bir statü üretmek veya toplum içi saygınlık kazanmak maksadından sıyrılarak, ihtiyaç temelli yeni bir forma bürünmüştür. Ayrıca, tüketim toplumunda var olabilmek için sürekli tüketmek durumunda olan bireylerin (Baudrillard, 2021, s. 30) yerini, stok yapan tüketici profilleri almıştır. Bunun yanı sıra, Covid-19 salgını tüketicilerin alışveriş davranışlarında da birtakım değişikliklere sebep olmuştur. Fiziki alışverişin sınırlamalara tabi tutulduğu karantina döneminde, tüketiciler alışveriş yapmak için yoğun olarak çevrim içi mecraları tercih etmişlerdir. Salgın döneminde yapılan çalışmalar (Alaimo vd., 2020; Danışmaz, 2020; Li vd., 2020), bireylerin çevrim içi alışveriş yapma sıklıklarının bu süreçte arttığını göstermektedir. 
Derleme bir araştırma niteliği taşıyan bu çalışmada, tüketim ve tüketim toplumu kavramlarının değerlendirilmesinin yanı sıra, bireylerin tüketim davranışlarının Covid-19 pandemi sürecinde uğradığı değişime vurgu yapılmıştır. $\mathrm{Bu}$ değişimin daha net şekilde anlaşlabilmesi amacıyla literatür taraması yapılmış, alanyazında ilgili konu(ları) odağa alan araştırmalara ve bu araştırmalara ilişkin bulgulara yer verilmiştir. Başlangıcının üzerinden yaklaşık iki yıl geçmiş olmasına rağmen etkisini sürdüren Covid-19 salgını, tüketim ve tüketici davranışları bağlamında üzerinde düşünülmesi ve değerlendirilmesi gereken güncel araştırma konularından biri olma özelliğini korumaktadır.

\section{Kaynakça}

Adanır, O. (2011). Teknolojik gelişmeden nesne teknolojisine ya da toplumsal gelişme nasıl durakladı?. Özne Dergisi, 14, 7-22.

Adorno, T. (2004). Negative Dialectics. New York: Routledge.

Adorno, T. (2007). Minima Moralia. A. Doğukan ve A. Koçak (Çev.). İstanbul: Metis Yayınları.

Aktulay Çakır, T. M. (2014). Postmodern tüketim ve tüketicinin değişen özellikleri (Doktora tezi). Maltepe Üniversitesi Sosyal Bilimler Enstitüsü, İstanbul.

Alaimo, L. S., Fiore, M., and Galati, A. (2020). How the Covid-19 pandemic is changing online food shopping human behaviour in Italy. Sustainability, 12(22), 1-18.

Arnold, M. J., and Reynolds, K. E. (2003). Hedonic shopping motivations. Journal of Retailing, 79(2), 77-95.

Aslan, İ. Y. (1996). Tüketici Hukuku. Bursa: Ekin Yayınevi.

Azizoğlu, A. ve Altunışık, R. (2012). Postmodernizm, sembolik tüketim ve marka. Tüketici ve Tüketim Araştırmaları Dergisi, 4(2), 33-50.

Baker, Scott R., Farrokhnia, R. A., Meyer, S., Pagel, M., and Yannelis, C. (2020). How does household spending respond to an epidemic? Consumption during the 2020 covid-19 pandemic. The Review of Asset Pricing Studies, 10(4), 834-862.

Bakırtaş D. ve Demirhan, H. (2015), İhtiyaç ve istek paradoksu: İktisadi ve metafizik bir yaklaşım. Siyaset, Ekonomi ve Yönetim Araştırmaları Dergisi, 3(3), 71-87.

Baudrillard, J. (1988). Jean Baudrillard: Selected Writings. M. Poster (Ed.). Cambridge \& Stanford: Polity \& Stanford University Press.

Baudrillard, J. (2009). Gösterge Ekonomi Politiği Hakkında Bir Eleştiri. O. Adanır ve A. Bilgin (Çev.), İstanbul: Boğaziçi Üniversitesi Yayınevi.

Baudrillard, J. (2011). Nesneler Sistemi. O. Adanır ve A. Karamollaoğlu (Çev.), İstanbul: Boğaziçi Üniversitesi Yayınevi.

Baudrillard, J. (2012). İmkânsız Takas. A. Sönmezay (Çev.), İstanbul: Ayrıntı Yayınları. 
Baudrillard, J. (2012). Kusursuz Cinayet. N. Sevil (Çev.), İstanbul: Ayrıntı Yayınları.

Baudrillard, J. (2012). Neden Her Şey Hâlâ Yok Olup Gitmedi?. O. Adanır (Çev.), İstanbul: Boğaziçi Üniversitesi Yayınevi.

Baudrillard, J. (2013). Üretimin Aynası ya da Tarihi Materyalist Eleştiri Yanılsaması. O. Adanır (Çev.), İstanbul: Boğaziçi Üniversitesi Yayınevi.

Baudrillard, J. (2021). Tüketim Toplumu. N. Tutan ve F. Keskin (Çev.), İstanbul: Ayrıntı Yayınları.

Bauman, Z. (1999). Çalışma, Tüketicilik ve Yeni Yoksullar. Ü. Öktem (Çev.), İstanbul: Sarmal Yayınları, İstanbul.

Baumạ, Z. (2016). Küreselleşme - Toplumsal Sonuçları. Abdullah Yılmaz (Çev.), İstanbul: Ayrıntı Yayınları.

Bocock, R. (2005). Tüketim. İ. Kutluk (Çev.), İstanbul: Dost Kitabevi.

Çelik, S. (2009). Hazsal ve Faydacı Tüketim. İstanbul: Derin Yayınevi.

Danışmaz, A. T. (2020). Covid-19 salgınının tüketicilerin online alışveriş tercihine etkisi. Sosyal Bilimler Araştırma Dergisi, 9(2), 83-90.

Eichenbaum, M. S., Rebelo, S., and Trabandt, M. (2020). The macroeconomics of epidemics. NBER Working Papers 26882, National Bureau of Economic Research, Inc.

Featherstone, M. (2013). Postmodernizm ve Tüketim Kültürü. M. Küçük (Çev), İstanbul: Ayrıntı Yayınları.

Hirschman, E. C. and Holbrook, M. B. (1982). Hedonic consumption: Emerging concepts. Journal of Marketing, 46(3), 92-101.

Hız, G. (2011). Gelişmekte olan ülkelerde gösterişçi tüketim: Türkiye ile ilgili bir araştırma. Organizasyon ve Yönetim Bilimleri Dergisi, 3(2), 117-128.

Hopkinson, G. C. and Pujari, D. (1999). A factor analytic study of the sources of meaning in hedonic consumption. European Journal of Marketing, 33(3-4), $273-294$.

İnce, Ş. (2014). Toplumsal ve Kültürel Dönüşümlerin Gündelik Hayata Yansımaları: 2000’lerde Türkiye’nin Mutfă̆ı (Yayımlanmamış Doktora Tezi). Ankara Üniversitesi Sosyal Bilimler Enstitüsü, Ankara.

Joy, A and Wallendorf, M. (1996). "The Development of Consumer Culture in the Third World: Theories of Globalism and Localism" in Consumption and Marketing: Macro Dimensions (pp. 104-135). N. Dholakia, R. Belk, and A. Venkatesh (Eds.). Cincinnati, Ohio: South-Western College Publishing.

Kaban Kadığlu, Z. (2014). Tüketim İletişimi: Süreçler, Algılar ve Tüketici. İstanbul: Pales Yayınları.

Kellner, D. (1994). "Toplumsal Teori Olarak Postmodernizm: Bazı Meydan Okumalar ve Sorunlar”. M. Küçük (Der.), Modernite Versus Postmodernite içinde. Ankara: Vadi Yayınları. 
Khan, U., Dhar, R., and Wertenbroch, K. (2005). A behavioral decision theory perspective on hedonic and utilaritian choice. In Inside Consumption: Consumer Motives, Goals and Desires (pp. 144-163). London: Routledge.

Köse, H. (2008). Lefebvre ve modern gündelik hayatın toplumsal eleştirisi. Gazi Üniversitesi İletişim Fakültesi İletişim Kuram ve Araştırma Dergisi, 27, (1-19).

Kulak, Ö. (2017). Theodor Adorno: Kültür Endüstrisinin Kıskacında Kültür. İstanbul: İthaki Yayınları.

Kükrer, Ö. (2011). Üniversite öğrencilerinde hedonik tüketimin cinsiyete göre farklılaşması. Karadeniz Teknik Üniversitesi İletişim Araştırmaları Dergisi, 78-87.

Li, J., Hallsworth, A. G., and Coca-Stefaniak, J. A. (2020). Changing grocery shopping behaviours among Chinese consumers at the outset of the Covid-19 outbreak. Tijdschrift voor Economische en Sociale Geografie, 111(3), 574-583.

Odabaşı, Y. (2006). Tüketim Kültürü - Yetinen Toplumdan Tüketen Topluma. İstanbul: Sistem Yayıncılık.

Okullu, Ş. (2019). Jean Baudrillard’ın Düşüncesinde Tüketim Toplumu ve Insanın Yeri (Yüksek Lisans Tezi). Gazi Üniversitesi, Sosyal Bilimler Enstitüsü, Ankara.

Özgül, E. (2011). Tüketicilerin sosyo-demografik özelliklerinin hedonik tüketim ve gönüllü sade yaşam tarzları açısından değerlendirilmesi. Ege Akademik Bakıs, 11(1), 25-38.

Rogers, K., and Cosgrove, A. (2020). "Future Consumer Index: How Covid-19 is Changing Consumer Behaviors", https://www.ey.com/en_gl/consumer-products-retail/how-covid-19-could-cha nge-consumer-behavior (Erişim Tarihi: 16.09.2021).

Soylu, Ö. B. (2020). Türkiye’de Pandemi Dönemi Tüketici Davranışları COVID-19. Bursa: Ekin Yayınevi.

Şüküroğlu, V. K. (2017). Tüketim Kültüründe Tüketici Vatandaşlık ve Sosyal Sorumluluk (Yayınlanmamış Doktora Tezi). Gazi Üniversitesi, Sosyal Bilimler Enstitüsü, Ankara.

Toffoletti, K. (2014). Yeni Bir Bakışla Baudrillard. Y. Başkavak (Çev.), İstanbul: Kolektif Kitap.

Veblen, T. B. (2015). Aylak Sınıfın Teorisi. E. Kırmızıaltın ve H. Bilir (Çev.), Ankara: Heretik Yayıncılık.

Zorlu, A. (2016). Üretim ve Tüketim Teorileri. Ankara: Altınordu Yayınları.

Web_1, McKinsey \& Company (16.04.2020), https://www.mckinsey.com/tr/our-insights/mckinsey-consumer-after-covid19 (Erişim Tarihi: 15.09.2021). 
Web_2, Mediatrend (29.04.2020), https://mediatrend.mediamarkt.com.tr/arastirma-turk-halki-salginin-6-ayd an-fazla-surmeyecegine-inaniyor (Erişim Tarihi: 15.09.2021). 